Joanna Ozimska

Università di Łódź

https://doi.org/10.18778/8220-506-0.17

\title{
ELEMENTY WŁOSKOŚCI W POLSKIM NAZEWNICTWIE MIEJSKIM I WIEJSKICH MIKROSYSTEMACH TOPONIMICZNYCH
}

\begin{abstract}
Italianness in Polish street names and rural toponymic microsystems. The study focuses on street names in Polish cities, towns and villages, in particular it examines Italian references within contemporary Polish odonymy. The author has performed a semantic and structural analysis of 554 units, applying the classification proposed by K. Handke. The results from the study of name usage show that there are $0,20 \%$ of proper names referring to Italianness on Polish streets, and $2 \%$ of them are motivated. Most names derive from other proper names. The most common are street names taking origin from anthroponyms (44\%) - commemorate figures that are deemed to be important to the local community (saints, artists, musicians, patriots, explorers). They are followed by names derived from place names (20\% - cities, $11 \%$ - other toponyms). $7 \%$ of corpus are names derived from ethnonyms. On the other hand, there are street names not subject to the transonimisation process and they represent $12 \%$ of corpus. The paper also provides a list of the most frequent street names and information about geographical differentiation of urban and rural street names, as well as a short presentation of female street namesakes.
\end{abstract}

Keywords: urbanonymy, onomastics, street names, Italianness, odonym.

Słowa klucze: nazewnictwo miejskie, onomastyka, urbanonimia, włoskość, hodonim.

\section{Wprowadzenie}

„Nazewnictwo miejskie jako zespół znaków (urbanonimów) - czytamy u Z. Zagórskiego (2008: 13) - służących komunikacji językowej i społecznej funkcjonuje i rozwija się w zależności od uwarunkowań wewnętrznych i zewnętrznych (m.in. kulturowych)”. Onomastykon danego obszaru (Graf 2011: 111) charakteryzuje się otwartością (powiększanie i pomniejszanie zbioru nazw), poligenetycznością (wielość baz nazewniczych), spacjalnością (rozmieszczenie nazw w przestrzeni) oraz wielowarstwowością (współistnienie 
nazw nadanych w różnym czasie). Wspomniane cechy czynią systemy nazw ulicznych interesującym materiałem badawczym.

Podział administracyjny Polski ${ }^{1}$ obejmuje 16 województw, podzielonych na 314 powiatów i 66 miast na prawach powiatu, na których obszarze istnieje 2477 gmin miejskich, miejsko-wiejskich i wiejskich ${ }^{2}$. Liczba ulic, placów, mostów występujących w tej przestrzeni stanowi ogromny korpus badawczy i bezustannie podlega przemianom ${ }^{3}$.

Korzyści płynące z analizy hodonimów są liczne. Dzięki znajomości konkretnych jednostek zyskujemy wiedzę na temat wartości, utrwalonych w języku, które wydają się być istotne dla organów nazwotwórczych i dla lokalnych społeczności ${ }^{4}$. Otrzymujemy również dostęp do informacji o tendencjach kształtujących nazewniczy krajobraz miast i wsi. Badania tego obszaru wydają się interesujące nie tylko dla samych badaczy. Ich wyniki świadczą o użytkownikach danego języka, odpowiedzialnych za kształt sfery onimicznej, która ich otacza. Mogą zainteresować użytkowników innych języków, jeśli stanowią one źródło zapożyczeń i transferów kulturowych.

Wnikliwe prześledzenie elementów na mapie Łodzi pozwala ustalić, że na peryferiach miasta ulica Wtoska przekształca się w Sycylijską; w Warszawie - Sycylijska przechodzi płynnie w Sardyńska, natomiast Wtoska krzyżuje się z Padewską a ulica Capri łączy się ze Śródziemnomorską. Czy wśród nadawanych polskim ulicom nazw uda się dostrzec więcej odniesień do włoskobrzmiących zasobów języka, geografii i kultury? Niniejszy tekst podejmuje próbę przyjrzenia się obszarowi całej Polski w poszukiwaniu interesujących dla italianisty włoskich elementów w aktualnie obowiązującym polskim nazewnictwie ulic miast i wsi.

\section{Pojęcie włoskości - próba wskazania granic zjawiska}

Pojawiająca się w tytule rozdziału włoskość nie jest kategorią łatwą do zdefiniowania. Internetowe wydania słownika ${ }^{5}$ i encyklopedii PWN nie zawierają takiego hasła. Czerpiąc $\mathrm{z}$ definicji zaproponowanych przez włoskojęzyczne

1 Stan na 1 stycznia 2021.

2 stat.gov.pl/statystyka-regionalna/jednostki-terytorialne/podzial-administracyjny-polski/ [10/02/2021].

3 Według stanu na 1 stycznia 2021 roku liczba ulic, rond, skwerów, mostów, placów, wysp, itp. wynosiła 280.665 jednostek. W stosunku do okresu objętego badaniem - stanu na 27 lipca 2019 - nastąpił wzrost o 7419 nazw.

4 Nazwy ulic, skwerów, placów ustalane są na mocy uchwał rad gminy (w miastach: rad miejskich), a zatem leżą w gestii samorządów terytorialnych. Zakres działań i zadania gmin reguluje ustawa z dnia 8 marca 1990 (z późn. zm.).

5 sjp.pwn.pl/szukaj/wloskosc.html [10/10/2020]. 
źródła ${ }^{6}$, dowiadujemy się, m.in., że pojęcie italianità wiąże się z postrzeganiem obiektów jako włoskie lub właściwe Włochom, jeśli mają związek z językiem, zwyczajami, kulturą, cywilizacją, mentalnością.

Wybrane źródła anglojęzyczne ${ }^{7}$ są $\mathrm{w}$ definiowaniu włoskości jeszcze bardziej zachowawcze, wskazując jako definicję ,the quality or state of being Italian (as in character or allegiance)". Internetowy słownik Collins ${ }^{8}$ nie uwględnia terminu italianità.

Próbując rozeznać się w temacie włoskości poprzez przegląd blogów podróżniczych - a zatem sięgając do wyobrażeń różnych użytkowników języka na temat analizowanej kategorii - możemy zorientować się, że „włoskość to stan umysłu", sprowadzający się do atrakcyjnego dla ludzi z zewnątrz stylu życia i celebracji wszystkich jego aspektów. Jest to więc zjawisko budzące współcześnie raczej pozytywne konotacje, choć nie zawsze i nie wszędzie tak było. Przymusowa italianizacja po I wojnie światowej, która objęła nowo włączone do Włoch obszary ${ }^{10}$, raczej pozytywnie kojarzyć się nie może ${ }^{11}$.

Czy można czynnikiem czasu określić zasięg włoskości? Geograficznym wyznacznikiem jest obszar Półwyspu Apenińskiego i należących do Włoch wysp. Chociaż do utworzenia Królestwa Włoch, a następnie Republiki Włoskiej, doszło stosunkowo niedawno, nie da się przejść obojętnie wobec ogromnego dorobku kulturowego poprzednich epok, wypracowanego przez mieszkańców poszczególnych państw-miast. Biorąc pod uwagę powyższe obserwacje, jak również złożone kwestie tożsamości narodowej Włochów, na potrzeby niniejszego opracowania uznaje się za przejawy włoskości wszystkie odniesienia do postaci, wydarzeń i zjawisk, które mogą przywoływać na myśl Włochy bez wskazania konkretnej daty narodzin tego zjawiska. Kluczowy wydaje się w tym przypadku czynnik geograficzny, choć należy pamiętać, że działalność Włochów, np. artystyczna ${ }^{12}$, o której będzie mowa w dalszej części tekstu, nie ograniczała się tylko do obszaru Italii.

6 www.treccani.it/vocabolario/italianita/ [10/08/2020].

7 www.merriam-webster.com/dictionary/Italianity [10/08/2020].

8 www.collinsdictionary.com/spellcheck/english?q=italianness [20/02/2021].

9 uwielbiamwloskieklimaty.com/polskie-blogi-o-wloszech/ [10/10/2020], autostradadelsole.com/2017/11/wloskosc-to-jest-stan-umyslu.html [10/10/2020].

$10 \mathrm{Na}$ przykład Południowy Tyrol z ludnością niemieckojęzyczną i ladyńską, histmag.org/Poludniowy-Tyrol-kontra-Gorna-Adyga-15551/ [10/10/2020].

11 Dyskusja dotycząca włoskości zajmowała również mieszkańców szwajcarskiego kantonu Ticino, hls-dhs-dss.ch/de/articles/027283/2009-04-02/ [10/10/2020].

12 Chodzi, m.in. o architektów i malarzy tworzących na obszarze Polski, por. Długosz (2007), Tygielski (2010). 


\section{Nazewnictwo miejskie w wybranych opracowaniach naukowych}

W polskich kręgach naukowych badaniem nazewnictwa miejskiego zajmowali się i nadal zajmują naukowcy skupieni w różnych ośrodkach badawczych $^{13}$. Wśród najważniejszych nazwisk, którym zawdzięczamy rozwój badań nad nazewnictwem miejskim, należy wymienić Kwirynę Handke z Polskiej Akademii Nauk.

Badaczka prześledziła proces kształtowania się systemu nazewnictwa miejskiego, funkcjonowanie tegoż systemu (właściwości $[\ldots]$, czynniki go kształtujące, jego modyfikacje i zaburzenia), obce elementy w nazewnictwie miejskim, analizowała miejsce nazewnictwa miejskiego wśród innych systemów onomastycznych oraz fleksję i składnię nazw ulic. Badała również niektóre typy strukturalne nazw (Myszka, Wisz 2012: 23).

K. Handke (2010: 359-360) stworzyła kompleksową semantyczno-formalną klasyfikację wszystkich typów nazw miejskich, występujących w Polsce, $\mathrm{z}$ niewielkimi modyfikacjami wykorzystywaną $\mathrm{w}$ badaniach nazewnictwa po dziś dzień:
A. Typy znaczeniowe nazw ulic:

1. Nazwy pochodzące od innych nazw własnych:

a) od nazw osobowych (motywowana: Ogińskich ${ }^{14}$, pamiątkowa ${ }^{15}$ : Mickiewicza),

b) od nazw etnicznych i geograficznych (motywowana: Holenderska, pamiątkowa: Francuska),

c) od nazw miejscowości (motywowana: Krakowska, pamiątkowa: Wiedeńska),

d) od nazw topograficznych (motywowana: Wygon, pamiątkowa: Niemeńska).

2. Nazwy pochodzące od nazw pospolitych:

a) od nazwań ludzi (motywowana: Białoskórnicza, niemotywowana: $\mathrm{Hu}$ manistów),

13 Początkowo hodonimią zajmowali się w Polsce historycy. Onomaści dołączyli do nich w latach dwudziestych XX w., podejmując badania zarówno synchroniczne, jak i diachroniczne (Myszka, Wisz 2012: 22).

14 Wszystkie przykłady cytowane za K. Handke.

15 A. Cieślikowa (2010: 328) podziela pogląd J. Chojnackiego, aby mianem nazw pamiątkowych określać tylko te, które upamiętniają nazwy wydarzeń historycznych, wprowadzając bardziej precyzyjny termin uznaniowe, odnoszący się m.in. do patronów ulic. 
b) nazwy kulturowe, związane z działalnością człowieka (motywowana: Piwna, niemotywowana: Siarczana),

c) nazwy topograficzne (motywowana: Dtuga, niemotywowana: Sadowa),

d) nazwy przyrodnicze (motywowana: Brzozowa, niemotywowana: Rysia),

e) nazwy ekspresywne (motywowana: Poprawa, niemotywowana: Skapa),

f) nazwy od miejsc i zdarzeń dziejowych (motywowana: Olszynki Grochowskiej, pamiątkowa: Trzeciego Maja).

B. Typy strukturalne nazw ulic:

1. Nazwy identyczne formalnie z podstawą, od której się wywodzą (podstawą może być inna nazwa własna lub wyraz pospolity):

a) nazwy przymiotnikowe (Ciasna, Stara, Czysta, Dobra),

b) nazwy rzeczownikowe (Leszno, Dunaj, Okrag, Wolność).

2. Nazwy nieidentyczne formalnie z podstawą, od której się wywodzą:

a) nazwy tworzone za pomocą różnych przyrostków ${ }^{16}$ (Rzeźnicza : rzeźnik, Browarna : browar, Ratuszowa : ratusz, Pólkowska: Pólków),

b) nazwy tworzone od wyrażeń przyimkowych (Przyrynek : przy rynku, Podwale : pod watem, Nadwiślańska : nad Wista).

3. Nazwy o strukturze złożonej:

a) złożenia właściwe (Nowomiejska : Nowe Miasto, Świętojańska : Świętego Jana, Krzywoboczna : o krzywym boku),

b) zestawienia - nazwy więcej niż jednowyrazowe (Nowy Zjazd, Krzywe Koło, Waski Dunaj, Bitwy pod Grunwaldem).

Pozostając na obszarze polskiej nauki, należy wskazać opracowania z zakresu nazewnictwa poszczególnych miast ${ }^{17}-\mathrm{w}$ tym nieoficjalnego (por. Groblińska 2020) - i onomastyki literackiej (por. Szargotowie 2011; Rybicka 2008), poświęcone nazwom ulic tworzącym świat przedstawiony wybranych powieści. Badaniom poddawane są również tłumaczeniowe (por. Gliński 2017; Ozimska 2014) aspekty hodonimii. Zainteresowaniem badaczy na świecie cieszą się ponadto, oprócz wspomnianych powyżej (por. Moncla, Gaio, Joliveau, Le Lay, Boeglin i Mazagol 2019), studia porównawcze (por. Mori 2007), tendencje (por. Oto-Peralías 2017; Perono Cacciafoco i Tuang 2018) w kreowaniu hodonimii miast - ze szczególnym uwzględnieniem wpływów polityki (por. Chloupek 2019; Begonja 2006) - oraz zagadnienia genderowe (por. Jakovljević-Šević 2020).

16 Aby kompleksowo opisać polski system nazw miejskich przy zastosowaniu powyższej klasyfikacji, przyrostki trzeba by uzupełnić o zmiany niemające własności słowotwórczych, będące efektem deklinacji końcówki fleksyjne, np. formacje typu Antoni-ego (Most).

17 Por. Bieńkowska, Umińska-Tytoń (2013). Autorki przypominają - za Kwiryną Handke - że blisko 50 miast, głównie z Pomorza i Polski południowej, doczekało się już szczegółowych opracowań (2013: 5). 


\section{4. Źródło i opracowanie danych}

Dokonując przeglądu polskiego nazewnictwa miejskiego pod kątem wyekscerpowania nazw nawiązujących do kultury, historii i geografii Włoch, posłużono się bazą danych TERYT udostępnioną na stronie internetowej przez Główny Urząd Statystyczny ${ }^{18}$. Pozyskano kompletne informacje, obejmujące cały obszar Rzeczpospolitej Polskiej, aktualne na dzień 27/07/2019. Po usunięciu duplikujących się nazw ulic, placów, skwerów, mostów, uzyskano listę liczącą 36161 niepowtarzalnych jednostek. Przegląd niniejszej bazy pozwolił na wyodrębnienie 137 różnych hodonimów o interesującej z punktu widzenia tego opracowania proweniencji lub konotacji. Decyzję o przyporządkowaniu poszczególnych nazw do zbioru włoskobrzmiącego i kojarzącego się z Italią podejmowano w oparciu o akademicki background italianistyczny, sprawdzając każdorazowo nazwy, których geneza nie była jasna i oczywista. Uwzględniono również elementy nawiązujące do historii Półwyspu Apenińskiego, poprzedzającej powstanie Republiki Włoch.

Kolejnym krokiem było ustalenie częstotliwości, z jaką poszczególne nazwy występują na terenie Polski i stworzenie roboczej bazy, zawierającej wszystkie takie przypadki, wraz z dokładnym opisem (nazwa miasta lub wsi, określenie województwa). Zaobserwowano 554 powtarzalne jednostki. Następnie przystąpiono do uzupełnienia tabeli o dane onomastyczne, pozwalające na dostrzeżenie pewnych tendencji nazwotwórczych (por. typy znaczeniowe lub strukturalne nazw).

Pamiętając o tym, że pełna struktura nazw miejskich składa się z dwóch członów: utożsamiającego (np. ulica, plac, aleja, most, park) i odróżniającego (właściwa nazwa własna), analizie poddano ten ostatni, gdyż rodzaj nazywanego obiektu ${ }^{19}$ nie wydaje się szczególnie istotny dla wyodrębnienia i wskazania głównych tendencji nazwotwórczych.

\section{Modele strukturalne analizowanych nazw}

Stosując do analizy zgromadzonego materiału klasyfikację nazw zaproponowaną przez K. Handke, udało się ustalić, iż w systemie polskiego nazewnictwa miejskiego nawiązującego do szeroko pojętej włoskości występują cztery z sześciu typów strukturalnych nazw.

18 eteryt.stat.gov.pl/eTeryt/rejestr_teryt/udostepnianie_danych/baza_teryt/uzytkownicy_indywidualni/pobieranie/pliki_pelne.aspx? contrast=default [27/07/2019].

19 W zdecydowanej większości chodzi o nazwy ulic; do rzadkości należały nazwy alei, parków, skwerów, mostów. 
Najwięcej, bo aż 53\% ogólu przeanalizowanych hodonimów to nazwy o strukturze złożonej, więcej niż jednowyrazowe ${ }^{20}(3 \mathrm{~b})$, np. Romea i Julii, Świętej Klary z Asyżu, Bitwy pod Monte Cassino, Marka z Aviano.

Druga grupa, licząca $43,5 \%$ jednostek, to nazwy jednowyrazowe tworzone za pomocą przyrostków (2a), wśród których dominują odtoponimiczne przymiotniki, np. Adriatycka, Alpejska, Apenińska, Dolomitowa, Wenecka, Watykańska, Turyńska. Zaliczamy tu również jednowyrazowe nazwy odantroponimiczne, wyrażone w innym przypadku niż mianownik, np. Romea, Pinokia, Kolumba, Galileusza.

Zaledwie jedna nazwa może być traktowana jako złożenie właściwe (3a). Chodzi o ulicę Śródziemnomorską $a^{21}$ w Łodzi, Szczecinie i Warszawie, przy czym należy zaznaczyć, że nie jest to obiekt geograficzny kojarzący się wyłącznie z Italią.

Pozostałe nazwy, obejmujące $3 \%$ zbiór, to jednostki uzyskane na skutek przeniesienia do kategorii hodonimów wybranych toponimów i antroponimów (1b), przywołujących skojarzenia z półwyspem Apenińskim, przy czym nazwy te są identyczne ${ }^{22} \mathrm{z}$ podstawą, od której się wywodzą, np. ulice Wenecja, Portofino, Solferino, Florencja, Capri, Beatrycze, Pinokio.

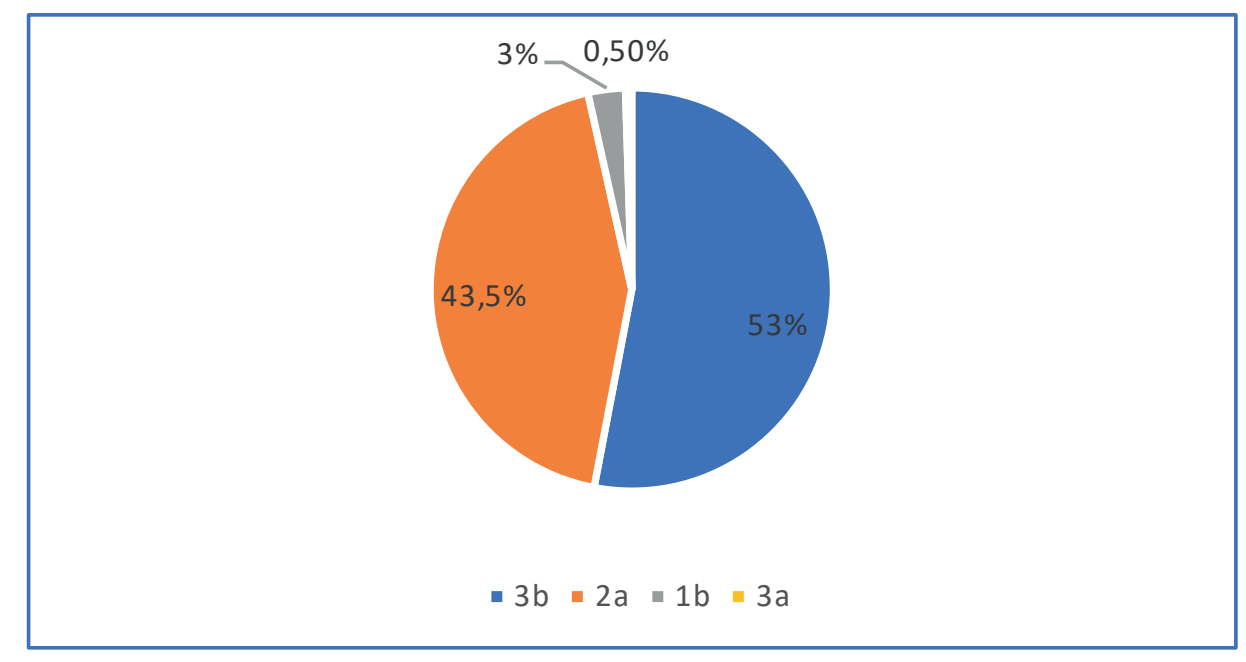

Wykres 1. Typologia strukturalna analizowanych nazw

Źródło: opracowanie własne.

$20 \mathrm{~W}$ tej grupie uwzględniono również nazwy dwuwyrazowe o schemacie imię i nazwisko postaci historycznej w dowolnym przypadku deklinacyjnym, np. Marco Polo, Marca Polo, wraz z przydawkami przymiotnikowymi lub rzeczownikowymi, np. Putkownika Francesco Nullo, Btogostawionego Luigiego Novarese.

21 Derwat hydronimu Morze Sródziemne.

22 Zgodność dotyczy polskiego odpowiednika włoskiej nazwy. 
Analiza strukturalna pokazała dodatkowo częściowy brak spójności w polskim systemie nazewnictwa miejskiego. Nazwy wywodzące się od tych samych desygnatów, np. odnoszące się do postaci historycznej Francesca Nulla ${ }^{23}$, włoskiego bohatera powstania styczniowego, funkcjonują w wielu miastach Polski w ramach różnych modeli strukturalnych, np. Francesca Nulla (Warszawa), Francesco Nullo (Jaworzno, Krzykawka, Olkusz, Skała, Sławków, Słupsk), Putkownika Francesco Nullo (Kraków), Pułkownika Franciszka Nulla (Wrocław). Odmiana nazw własnych, w tym imion i nazwisk, składających się na człon odróżniający hodonimu, zdaje się stanowić trudność dla użytkowników języka polskiego. Jako przykład można przywołać ulice Giordano Bruno (Zabrze), Giordana Bruna (Warszawa). Nominacje tego typu można by długo wymieniać.

\section{Semantyka analizowanych nazw}

Rozważania dotyczące semantyki polskich hodonimów inspirowanych Italią należy rozpocząć od ustalenia jaki odsetek nazw ma związek motywacyjny z nazywanym obiektem. Jak przypomina Handke (2010:360)

We wczesnych okresach dziejów polskich miast nazewnictwo powstawało spontanicznie w codziennych kontaktach mieszkańców. Wynikało to z dążności człowieka do poznania otaczającego świata i potrzeby zorganizowania w tym świecie życia społecznego. (...) Nazwę motywowały: wygląd, charakter lub funkcja obiektu. Nazwa jako znak językowy zawierała treść zrozumiałą dla odbiorcy, który wiedzial, że ulica Zakroczymska ma realny związek z Zakroczymiem, do którego prowadzi, a nazwa Piekarska wiąże się z zawodem mieszkańców ulicy itd.

Współcześnie trudno o taką transparentność nazewnictwa miejskiego. Jednakże $\mathrm{w}$ analizowanym materiale udało się wyodrębnić jednostki, powiązane logicznie z określanym obiektem lub jego okolicą. Przykładem takiej nazwy własnej jest człon Benedyktyńska ${ }^{24}$ stosowany $\mathrm{w}$ odniesieniu do nazw ulic. Większość stanowią nazwy pamiątkowe (Cieszyn, Mielec, Pultusk, Starachowice, Ścinawa, Zabrze, Wrocław). Jednak o swoistej motywacji możemy mówić w przypadku ulicy Benedyktynów (wieś Legnickie Pole), Ojców Benedyktynów (wieś Sieciechów) lub Benedyktyńskiej (Drohiczyn, Jarosław, Kraków, Krze-

23 www.treccani.it/enciclopedia/francesco-nullo/ [10/09/2020].

24 Święty Benedykt z Nursji, autor reguły benedyktyńskiej, założyciel klasztoru na Monte Cassino, w sposób niekwestionowany może być kojarzony z półwyspem Apenińskim, co pozwala na włączenie w krąg zainteresowań badawczych 14 występujących na obszarze Polski hodonimów Benedyktyńska i Benedyktynów. 
szów, Mogilno), gdyż przy tak nazwanych ulicach znajdują się klasztory męskie lub żeńskie, żyjące według reguły św. Benedykta ${ }^{25}$, a zatem wywodzące się z półwyspu Apenińskiego.

Podobny akt nazewniczy miał miejsce w przypadku ulicy błogosławionego Luigiego Novarese (Głogów), przy której ulokowano Wspólnotę Cichych Pracowników Krzyża ${ }^{26}$.

Nadanie ulicy nazwy wynikającej z umiejscowienia na niej obiektów, zasługujących na wyróżnienie, ale nieodnoszące się do działalności religijnej, dotyczy kolejnego z analizowanych przypadków. W Radomsku w 2007 roku uhonorowano założyciela firmy Indesit, Aristide Merloniego, nadając jego imię traktowi prowadzącemu do nowo powstałej fabryki ${ }^{27}$. Z kolei w Jeleniej Górze jedna z ulic nosi nazwę Cervi ${ }^{28}$, co ma bezpośredni związek ze współpracą partnerską między tymi dwoma miastami. Partnerstwo miast uhonorowano również w Gnieźnie, jeden ze skwerów zyskał nazwę im. Miasta Anagni. W tych przypadkach abstrakcyjna więź między Polską i Włochami przybrała konkretny i realny wymiar widoczny na obszarze hodonimii.

Do nazw motywowanych możemy zaliczyć również ulicę Elii Marchettiego w Chorzowie. Marchetti ${ }^{29}$ był uczestnikiem powstania styczniowego i zmarł na terenie Chorzowa, gdzie został pochowany.

Konkludując, ta część badania wykazała, że jedynie $2 \%$ nazw miejskich nawiązujących do włoskości, których genezę powstania udało się ustalić, ma charakter motywowany. Pozostałe jednostki funkcjonują w oparciu o arbitralne decyzje i brak związku nazwy z najbliższym otoczeniem.

Jeśli chodzi o pełny opis analizowanego materiału z perspektywy semantycznej, bazując ponownie na wspomnianej klasyfikacji K. Handke, okazało się, że $82 \%$ wszystkich analizowanych nazw pochodzi od innych nomina propria. Najliczniej reprezentowana jest grupa hodonimów wywodzących się od nazw osobowych $(44 \%, 1 a)$, co wydaje się naturalne z uwagi na chęć uhonorowania zasłużonych dla Europy i świata postaci historycznych. W tej grupie znajdują się osobistości kojarzone z religiąa ${ }^{30}$ (np. ulice świętego Ojca Pio, Piusa XI, Toma-

25 W Mogilnie chodzi dla odmiany o Klasztor Zakonu Braci Mniejszych Kapucynów.

26 www.cisi.pl/ [10/09/2020].

27 lodz.wyborcza.pl/lodz/1,35136,4694363.html?disableRedirects=true $[10 / 09 / 2020]$.

28 Nazwa pochodząca od toponimu Cervia, miasta położonego w rejonie Emilia-Romania, www.comunecervia.it/ [10/09/2020].

29 www.straznicyczasu.pl/viewtopic.php?t=970 [10/09/2020].

30 Utworzone w ten sposób nazwy ulic, placów, alei, mostów, L. Przybylska określa mianem hierotoponimów (2015: 270). W międzynarodowej literaturze onomastycznej stosuje się raczej w takich przypadkach pojęcie hagiotoponimu, por. Lista 
sza z Akwinu, św. Dominika Savio ${ }^{31}$ ), sztuką (Da Vinci, Michała Anioła, Canaletta, Antonia Corazziego, Pompeo Ferrariego), literaturą (Dantego Alighieri, Carla Goldoniego, Arlekina), muzyką (Antonia Vivaldiego, Giuseppe Verdiego, Gioacchino Rossiniego, Giacomo Pucciniego, Pavarottiego, Arcangela Corellego, Niccola Paganiniego), nauką (Galilieusza, Guglielmo Marconiego), polityką (Generała Giuseppe Garibaldiego), odkrywaniem świata (Marco Polo, Krzysztofa Kolumba).

Druga pod względem liczebności grupa to nazwy derywowane od nazw miejscowości (1c), stanowiące $20 \%$ korpusu. Dużą popularnością cieszą się hodonimy Wenecka, Wenecja, ale i Monte Cassino, które można postrzegać jako włoskie miasto o wyjątkowym znaczeniu dla Polaków. Na wzmiankę ze względu na umiarkowaną powtarzalność zasługują również ulice Rzymska, Loterańska, Turyńska i Florencka. Natomiast nazwy Bolońska, Mesyńska, Pompejańska, Portofino, Solferino pojawiają się na mapie polskich ulic jednokrotnie.

Pozostając w kręgu nazw odproprialnych, trzeba wspomnieć o kolejnej licznej i dobrze reprezentowanej grupie pochodzącej od pozostałych nazw geograficznych (1d), wykorzystujących nazwy mórz, pasm górskich, regionów, wysp. Kategoria ta dotyczy $11 \%$ wszystkich analizowanych jednostek. Motywy górskie reprezentują ulice Alpejska, Apenińska, Dolomitowa. Spośród 20 regionów Włoch na ulicach polskich miast można dostrzec hodonimiczne odniesienia do tych najbardziej popularnych i atrakcyjnych turystycznie, świadczą o tym ulice Toskańska, Sycylijska, Sardyńska. Dwie ostatnie nazwy mogą być jednocześnie traktowane jako derywacje od nazw wysp. W tej grupie nazw pamiątkowych pojawia się jeszcze warszawska ulica Capri. Jeśli chodzi o morza oblewające półwysep Apeniński, polskie nazewnictwo miejskie odnotowuje ulice Adriatycką, Tyrreńską i wspomnianą Śródziemnomorską.

Ostatnia grupa nazw - wywodzących się od etnonimów (1b) - obejmuje lącznie 7\% wszystkich analizowanych jednostek, ale w praktyce sprowadza się do dwóch powtarzających się nazw - ulic Watykańska i Wtoska, ze znaczną przewagą liczebną tej ostatniej.

Na tym kończą się przykłady nazw ulic utworzone w drodze procesów trasnonimizacyjnych. Pozostałe kategorie nazw czerpią z zasobów apelatywnych, przy czym związek z Italią bywa w tym przypadku mniej bliski niż ma to miejsce w przypadku analizowanej uprzednio kategorii nomina propria. W toku badań udało się ustalić, że $12 \%$ korpusu stanowią nazwy pochodzące od zdarzeń dziejowych (2f), np. ulice, aleje, rondo Bitwy pod Monte Cassino, Bohaterów Monte Cassino, Zwycięzców spod Monte Cassino. Jak widać również w tym przypadku

ICOS kluczowych terminów onomastycznych, tłum. i oprac. Artur Gałkowski i Urszula Bijak, Grupa Terminologiczna ICOS International Council of Onomastic Sciences, Łódź-Kraków 2018, s. 2.

31 www.dominik.salezjanie.pl/dominik/?d=1 [11/09/2020]. 
oprócz kluczowego apelatywu, człon odróżniający bazuje na nazwie własnej, związanej z obszarem Włoch. W ten sam nurt wpisuje się nazwa ulic Czerwone Maki, Czerwonych Maków, upamiętniająca heroiczne zwycięstwo polskich żolnierzy pod wodzą gen. Władysława Andersa.

Nazwy kulturowe, związane z działalnością człowieka, pochodzące od nazw pospolitych (2b) są reprezentowane przez ulicę Renesansowa i nie przekraczają $1 \%$ korpusu.

Ostatnia kategoria, którą nie bez obaw ${ }^{32}$, zdecydowałam się wyodrębnić, to nazwy przyrodnicze, niemotywowane, ale mogące budzić skojarzenia z kulinarną spuścizną Włoch. Chodzi o dwie ulice, dość popularne, jeśli uwzględnić częstotliwość występowania, Bazyliowa i Rukoli33. Ogółem stanowią 5\% przeanalizowanego korpusu.

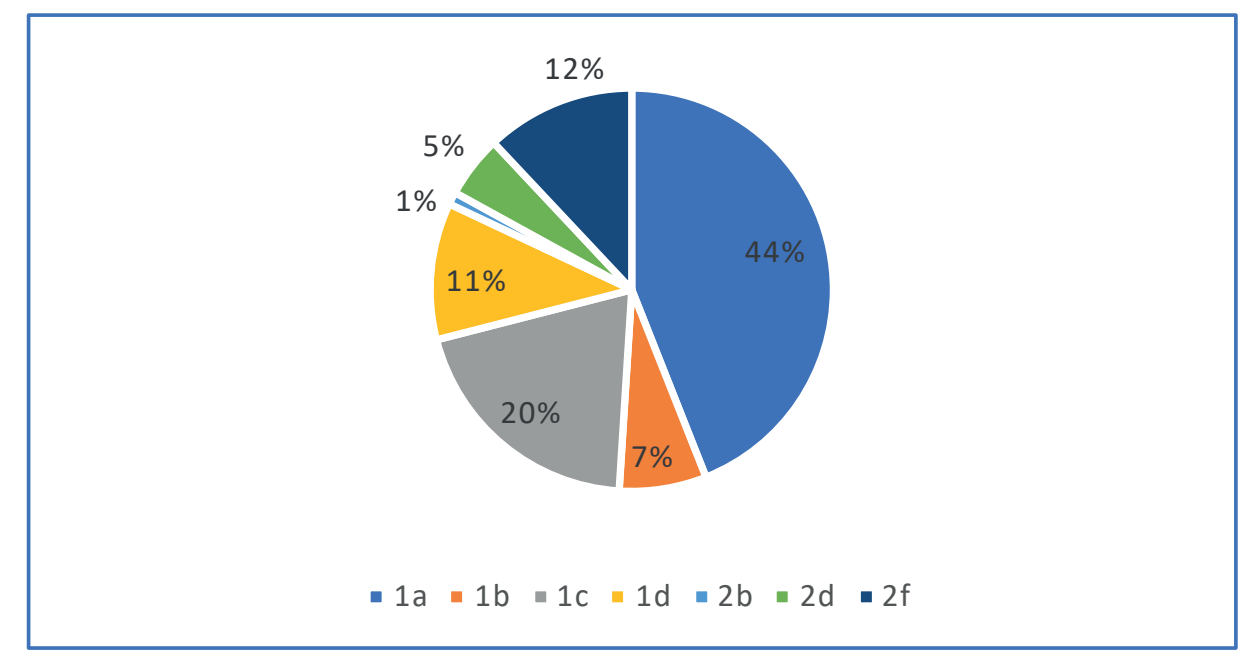

Wykres 2. Typologia semantyczna analizowanych nazw

Źródło: opracowanie własne.

32 Obawy wynikają z braku ścisłego związku z Włochami. Tym niemniej, produkty roślinne, które dały początek zaliczonym do tej kategorii nazwom, w ogromnym stopniu wykorzystywane są w kuchni włoskiej i mogą przywodzić na myśl m.in. Italię.

33 WWarszawie pojawienie sięna mapie ulicy Rukolibyło wynikiem zmiany poczynionej przez radnych pod naciskiem mieszkańców Wilanowa, którzy nie chcieli mieszkać przy ulicy Rzeżuchowej. warszawa.wyborcza.pl/warszawa/1,54420,15287880,Ulica_Rukoli_zamiast_Rzezuchowej_Tak_chcieli_w_Wilanowie.html[20/11/2020]. 


\section{Uwagi końcowe}

Biorąc pod uwagę liczebność polskich nazw miejskich kojarzących się z włoskością, należy zauważyć, że w obrębie całego systemu hodonimicznego Polski stanowią one niewielki ich odsetek: 0,38\% wszystkich unikalnych jednostek. Jeśli analizie poddamy cały zasób hodonimii polskiej, nie wykluczając powtarzających się $\mathrm{w}$ wielu lokalizacjach toponimów - ponad 270.000 obiektów - okaże się, że nazw kojarzących się z Belpaese na polskich ulicach odnotujemy jeszcze mniej: zaledwie $0,20 \%$. Otrzymany wynik jest w pełni zrozumiały. Nazewnictwo miejskie w pierwszej kolejności dąży do upamiętnienia lokalnych bohaterów i ważnych dla danej społeczności wydarzeń historycznych. W ostatnim czasie - biorąc pod uwagę ciągłe zmiany w tkance miejskiej i tworzenie nowych ulic - nie były prowadzone badania porównawcze, ukazujące wpływy innych kultur - elementów obcych - na warstwę hodonimiczną Polski, ale wydaje się zasadna hipoteza, że włoskość na tym tle i tak wypada zaskakująco dobrze ${ }^{34}$. Potwierdza to tylko silne wpływy i powiązania włosko-polskie, nieograniczające się jedynie do wyrażania wzajemnej sympatii. Ale i może świadczyć o dużym znaczeniu Włoch w historii ogólnoświatowej.

Najwięcej obiektów o interesujących nas właściwościach stwierdzono w mieście stołecznym Warszawie (43 nazwy). Jednocześnie warszawskie hodonimy w największym stopniu podlegają zasadom prawidłowej odmiany nazw własnych, co niekoniecznie dotyczy pozostałego obszaru kraju.

Obecność kojarzących się z Włochami nazw miejskich w innych miastach i ośrodkach wiejskich obrazuje poniższa tabela:

Tabela 1. Rozmieszczenie geograficzne analizowanych nazw - miasta i wsi

\begin{tabular}{|l|c|}
\hline \multicolumn{1}{|c|}{ Nazwa miasta lub wsi } & $\begin{array}{c}\text { Ilość } \\
\text { zaobserwowanych } \\
\text { hodonimów }\end{array}$ \\
\hline \multicolumn{1}{|c|}{1} & 2 \\
\hline Warszawa & 43 \\
\hline Wrocław & 15 \\
\hline Łódź & 12 \\
\hline Poznań, Szczecin & 11 \\
\hline Kraków & 10 \\
\hline
\end{tabular}

34 Gdyby poddać badaniu ilu francuskich czy niemieckich bohaterów narodowych patronuje polskim ulicom, ten odsetek mógłby się okazać niższy niż w przypadku wpływów włoskich. 


\begin{tabular}{|c|c|}
\hline 1 & 2 \\
\hline Białystok, Częstochowa & 7 \\
\hline Lublin, Bydgoszcz & 6 \\
\hline Gdańsk, Gdynia, Rzeszów, Zabrze & 5 \\
\hline Opole, Radomsko, Tarnowo Podgórne, Tarnowskie Góry & 4 \\
\hline $\begin{array}{l}\text { Bieruń, Chylice, Ciechanów, Jarosław, Kalisz, Katowice, Klau- } \\
\text { dyn, Legnica, Łomża, Mińsk Mazowiecki, Młochów, Olsztyn, } \\
\text { Ostrzeszów, Radom, Siedliska, Słupsk, Tarnów, Zielona Góra }\end{array}$ & 3 \\
\hline $\begin{array}{l}\text { Białe Błota, Bielawa, Bielsko-Biała, Biłgoraj, Chotomów, } \\
\text { Chrzanów, Czersk, Dąbrowa Górnicza, Ełk, Gliwice, Głogów, } \\
\text { Głowno, Gorzów Wielkopolski, Jabłonna, Jasło, Jaworzno, } \\
\text { Jelcz-Laskowice, Jelenia Góra, Kielce, Kobylnica, Kołobrzeg, } \\
\text { Krotoszyn, Krzeszów, Majdan, Niemcz, Oława, Ostrołęka, } \\
\text { Ostrów Wielkopolski, Owczarnia, Prudnik, Pruszcz Gdański, } \\
\text { Pruszków, Przecław, Radom, Robakowo, Sędziszów Mało- } \\
\text { polski, Siedlce, Sierpc, Sokołów Podlaski, Sokółka, Stargard, } \\
\text { Tczew, Tokary, Toruń, Tychy, Wadowice, Wałbrzych, Witnica, } \\
\text { Zalasewo, Zielona Łąka }\end{array}$ & 2 \\
\hline $\begin{array}{l}\text { Aleksandrów Łódzki, Antoninów, Baranów Sandomierski, Bar- } \\
\text { toszyce, Bełchatów, Bezrzecze, Biała Podlaska, Bieruń, Bilcza, } \\
\text { Bojano, Bolesławiec, Bolszewo, Brańsk, Brwilno, Brzeg, Brze- } \\
\text { sko, Brzeziny, Brzozówka, Budy-Grzybek, Busko-Zdrój, Bytom, } \\
\text { Chęciny, Chmielów, Chorzele, Cieszyn, Czechowice-Dziedzice, } \\
\text { Czernica, Czerniewice, Częstochowa, Dachowa, Dęblin, Do- } \\
\text { broszków Oleśnicki, Domaszowice, Drohiczyn, Elbląg, Fasty, } \\
\text { Garlica Murowana, Garwolin, Gądki, Giebułtów, Głuchowo, } \\
\text { Gniezno, Golina, Gołubie, Gomulin-Kolonia, Góra Kalwaria, } \\
\text { Góra Siewierska, Grabówka, Grądy, Grodzisk Mazowiecki, } \\
\text { Gromnik, Grójec, Harbutowice, Henryków-Urocze, Janinów, } \\
\text { Janowiec, Janów, Jasin, Jonkowo, Kałduny, Kałęczyn, Kamien, } \\
\text { Karakule, Kąty, Kępno, Kętrzyn, Kiekrz, Knyszyn, Kobylanka, } \\
\text { Kołaczyce, Komorniki, Konin, Konstancin-Jeziorna, Kopanka, } \\
\text { Koronowo, Korycin, Korzkwy, Kosakowo, Kostrzyn nad Odrą, } \\
\text { Koszalin, Kozery Nowe, Kozia Góra, Krasnystaw, Krosno, Kry- } \\
\text { nica Morska, Krzepice, Krzykawka, Kutno, Latowicz, Legnickie } \\
\text { Pole, Leszno, Lębork, Lubaczów, Lubartów, Łagów, Łasz- } \\
\text { czówka, Łbiska, Łęgowo, Łomianki Dolne, Łowicz, Makówka, } \\
\text { Marki, Maszna, Miedziana Góra, Mielec, Mierzyn, Mierzynek, } \\
\text { Modła, Mogilany, Mogilno, Morąg, Morzyczyn, Mrowiska, } \\
\text { Mysłowice, Nadbrzeż, Nadma, Nasielsk, Nasławice, Niemcz, } \\
\text { Niepołomice, Nikielkowo, Nisko, Nowa Ruda, Nowa Wieś } \\
\text { Ełcka, Nowa Wieś Szlachecka, Nowa Wola, Nowogard, Nowy } \\
\text { Konik, Nowy Sącz, Nowy Żmigród, Nurzec-Stacja, Oborniki } \\
\text { Śląskie, Oleśnica, Olkusz, Opacz-Kolonia, Osieck, Osiecznica, } \\
\text { Osielsko, Ostre, Ostróda, Ostrów Mazowiecka, Oświęcim, } \\
\text { Otwock, Ożarów, Perlino, Piaseczno, Pisarzowice, Plewiska, } \\
\text { Płock, Płońsk, Proszowice, Przeczyce, Przemyśl, }\end{array}$ & 1 \\
\hline
\end{tabular}


Tab. 1 (cd.)

\begin{tabular}{|c|c|}
\hline 1 & 2 \\
\hline $\begin{array}{l}\text { Przytoczna, Psary Polskie, Pułtusk, Puste Łąki, Pyskowice, } \\
\text { Racibórz, Radawa, Radomice, Reda, Regulice, Resko, Rogów } \\
\text { Sobócki, Ropczyce, Rozalin, Różan, Różanka, Rumia, Rusino- } \\
\text { wo, Rybienko Nowe, Rybnik, Rydzyna, Sanok, Serock, Sęko- } \\
\text { cin Stary, Sieciechów, Siedlec, Siekierki Wielkie, Siemiatycze, } \\
\text { Skała, Skawina, Skierniewice, Skórzewo, Sławków, Sochonie, } \\
\text { Solec Kujawski, Sopot, Sosnowiec, Sośnica, Stalowa Wola, } \\
\text { Stanisławów, Stara Łomża przy Szosie, Starachowice, Starogard } \\
\text { Gdański, Strachów, Strzałków, Strzyżów, Sulejówek, Sulnówko, } \\
\text { Swadzim, Szewce, Szreniawa, Scinawa, Sroda Wielkopolska, } \\
\text { Świebodzice, Świnoujście, Tomaszów Mazowiecki, Trzciane, } \\
\text { Trzebnica, Tuszyn, Twardorzeczka, Tyniec Mały, Warszawian- } \\
\text { ka, Węgrów, Wieprz, Wierzchucino, Włosań, Woctawy, Wojcie- } \\
\text { szyce, Wojnicz, Wojnówko, Września, Wysokie Mazowieckie, } \\
\text { Wyszków, Zabór, Zamość, Zaścianki, Zawiercie, Ząbkowice Ślą- } \\
\text { skie, Zielonka, Złocieniec, Złotoryja, Żabieniec, Żory, Żyrardów }\end{array}$ & 1 \\
\hline
\end{tabular}

Źródło: opracowanie własne.

Terytorialne rozmieszczenie badanych nazw na obszarze poszczególnych województw prezentuje poniższa mapa:

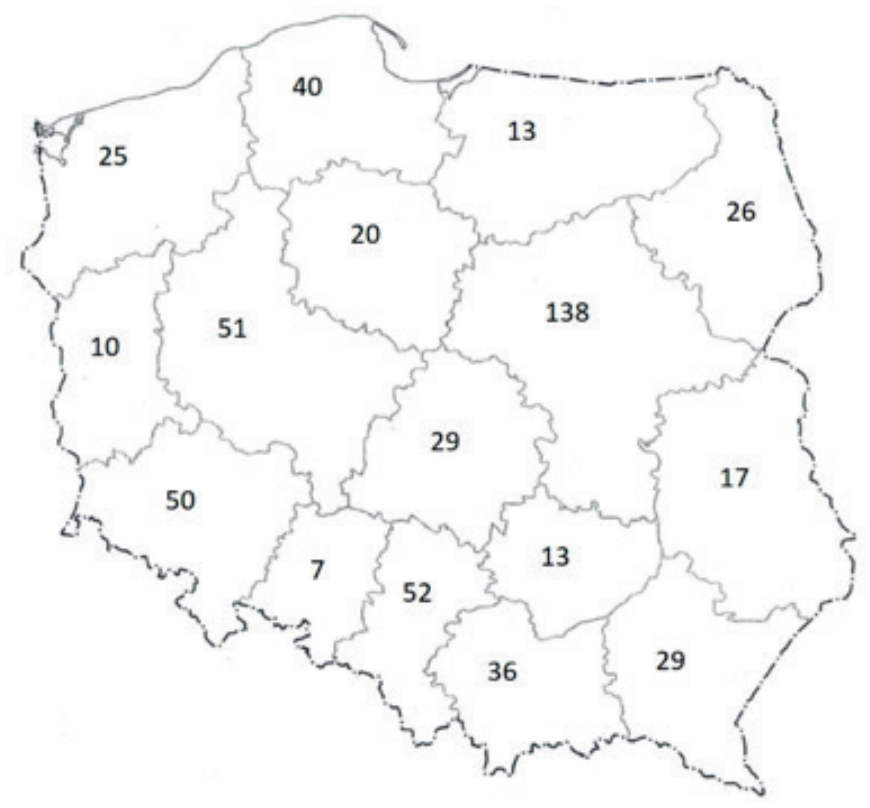

Mapa 1. Rozmieszczenie geograficzne analizowanych nazw - województwa

Źródło: opracowanie własne. 
Jeśli chodzi o obecność w hodonimii włoskich postaci kobiecych (por. Gałkowski 2020), jest ona znikoma i ogranicza się do trzech postaci: Beatrycze, św. Klary z Asyżu, Królowej Bony, Bony, Bony Sforzy. Ostatni przykład jest zarazem inspirowanym półwyspem Apenińskim hodonimem najczęściej występującym na ulicach polskich miast. Funkcjonuje w 49 lokalizacjach. Kolejne pod względem popularności są ulice Bohaterów Monte Cassino (37 lokalizacji), Monte Cassino (35), Wtoska (32), Wenecka (29), Bazyliowa ex equo z ul. św. Antoniego (27), Dolomitowa (19), Alpejska (18), Czerwonych Maków (17). Na następnych miejscach uplasowały się ulice Rzymska (15), Krzysztofa Kolumba (13), Benedyktyńska i Galileusza (12), św. Ojca Pio (10), Toskańska (8), Loretańska (7), Watykańska i Wenecja (6).

Zazwyczaj opracowania dotyczące hodonimii skupiają się na miejskich systemach nazewniczych z uwagi na dużą liczebność poddawanych badaniu jednostek. Analiza danych pochodzących z całej Polski pokazała, że niemal $30 \%$ spośród zaobserwowanych 554 włosko kojarzących się hodonimów, znajduje się na obszarach wiejskich. To znaczący odsetek a występujące na tych terenach nazwy ulic nie różnią się specjalnie od tych nadawanych w miastach ${ }^{35}$.

Podsumowując, dane zebranie podczas badania pozwoliły potwierdzić widoczną obecność Włoch na ulicach polskich miast, miasteczek i wsi. I jest to obecność dużo większa niż można by przypuszczać, dowodząca, że polski zasób urbanonimii czerpie z wielu źródeł i nieustannie się rozwija.

\section{Bibliografia}

Begonja, Zlatko (2006). „Odonimi kao ideološke manifestacije na primjeru Zadra”, Radovi Zavoda za povijesne znanosti HAZU u Zadru, 48, s. 703-720.

Bieńkowska, Danuta i Umińska-Tytoń, Elżbieta (2013). Nazewnictwo miejskie Łodzi, Łódź, Wydawnictwo Uniwersytetu Łódzkiego.

Chloupek, Brett R. (2019). "Public memory and political street names in Košice: Slovakia's multiethnic second city”, Journal of Historical Geography, 64, s. 25-35, https://doi. org/10.1016/j.jhg.2018.11.007

Cieślikowa, Aleksandra (2010). „Historia, tradycja i teraźniejszość obecne dzięki antroponimom w nazwach ulic Krakowa”, [in] Irena Sarnowska-Giefing i Magdalena Graf (red.),

35 Wyekscerpowane w badaniu nazwy ulic gmin wiejskich: Alpejska, Arlekina, Bazyliowa, Benedyktynów, Benedyktynów Ojców, Benedyktyńska, Bohaterów Monte Cassino, Czerwone Maki, Czerwonych Maków, Da Vinci, Dolomitowa, Florencka, Galileusza, Kolumba, Królowej Bony, Loretańska, Marco Polo, Merliniego, Michała Anioła, Monte Cassino, Nullo Francesco, Paganiniego Niccolo, Pinokia, Pinokio, Świętego Ojca Pio, Piusa XI, Pompejańska, Renesansowa, Rukoli, Rzymska, Sycylijska, Św. Dominika Savio, św. Franciszka z Asyżu, Świętego Antoniego, Tomasza z Akwinu, Toskańska, Turyńska, Verdiego Giuseppe, Vivaldiego Antonia, Watykańska, Wenecja, Wenecka, Włoska. 
Miasto w perspektywie onomastyki i historii, Poznań, Wydawnictwo Poznańskiego Towarzystwa Przyjaciół Nauk, s. 325-335.

Długosz, Dominika (2007). „Śladami Włochów w Polsce od XVI do XVIII wieku. Region Świętokrzyski”, Rocznik Muzeum Narodowego w Kielcach, 23, s. 167-192.

Gałkowski, Artur (2020). "Feminine urbanonymy in Polish and Italian linguistic landscapes", Lege artis. Language yesterday, today, tomorrow. The journal of University of SS Cyril and Methodius in Trnava, 1, czerwiec 2020, s. 2-53.

Gliński, Marcin (2017). „O tłumaczeniu nazw własnych przez Mirosławę Czarnocką-Wojs w opowieściach Beatrix Potter“, [in] Jolanta Lubocha-Kruglik i Oksana Małysa (red.), Przestrzenie przekładu T. 2, Katowice, Wydawnictwo Uniwersytetu Śląskiego, s. 189-199.

Graf, Magdalena (2011). „Człowiek wobec onimicznej przestrzeni miasta - kilka uwag o współczesnej urbanonimii”, Onomastica, LV, s. 107-118.

Groblińska, Justyna (2020). Nieoficjalne nazewnictwo miejskie Łodzi. Stownik, Łódź, Wydawnictwo Uniwersytetu Łódzkiego.

Handke, Kwiryna (2010). „Konstrukcja i dekonstrukcja systemu nazewnictwa miejskiego w polskich miastach", [in] Irena Sarnowska-Giefing i Magdalena Graf (red.), Miasto w perspektywie onomastyki i historii, Poznań, Wydawnictwo Poznańskiego Towarzystwa Przyjaciół Nauk, s. 357-372.

Jakovljević-Šević, Tijana (2020). "What is the gender of a city? Odonyms and spatial genderization: An example of the City of Novi Sad”, Glasnik Etnografskog Instituta SANU, 68, 1, s. 113-129, https://doi.org/10.2298/GEI2001113J.

Lista ICOS kluczowych terminów onomastycznych, tłum. i oprac. Artur Gałkowski i Urszula Bijak, Grupa Terminologiczna ICOS International Council of Onomastic Sciences, ŁódźKraków 2018.

Moncla, Ludovic i Gaio, Mauro i Joliveau, Thierry i Le Lay, Yves-François i Boeglin, Noémie i Mazagol, Pierre-Olivier (2019). "Mapping urban fingerprints of odonyms automatically extracted from French novels", International Journal of Geographical Information Science, 33, s. 2477-2497, https://doi.org/10.1080/13658816.2019.1584804.

Mori, Olga (2007). "Odonyms of Buenos Aires and Tarragona. A Comparative Approach", Onoma, 42, s. 89-109, https://doi.org/10.2143/ONO.42.0.2047076

Myszka, Agnieszka i Wisz, Piotr (2012). Nazwy ulic Rzeszowa. Historia i wspótczesność, Rzeszów, Biblioteka „Frazy”.

Nazewnictwo geograficzne Poznania. Zbiór studiów (2008), red. Zygmunt Zagórski, Poznań, Wydawnictwo Naukowe Uniwersytetu im. Adama Mickiewicza.

Oto-Peralías, Daniel (2017). "What do street names tell us? The 'city-text' as socio-cultural data”, Journal of Economic Geography, lbx030, https://doi.org/10.1093/jeg/lbx030.

Ozimska, Joanna (2014). "Le denominazioni proprie nella narrativa contemporanea polacca in una prospettiva traduttologica”, Il Nome nel testo, Rivista internazionale di onomastica letteraria, XVI, s. 301-311.

Perono Cacciafoco, Francesco i Tuang, Shu Qi (2018). "Voices from the streets: trends in naming practices of Singapore odonymy", Review of Historical Geography and Toponomastics, 25/26, s. 9-30.

Przybylska, Lucyna (2005). „Hierotoponimy. Przykład Gdyni”, Peregrinus Cracoviensis, 16, s. 93-100. 
Przybylska, Lucyna (2015). „Ulice św. Jakuba w Polsce”, [in] ks. Piotr Roszak i Franciszek Mróz (red.), Droga św. Jakuba w Polsce - historia, teraźniejszość, przyszłość. W 10. Rocznicę otwarcia pierwszego polskiego odcinka Camino de Santiago. Studia i materiaty dedykowane prof. dr. hab. Antoniemu Jackowskiemu, Kraków, Wydawnictwo «CZUWAJMY», s. 267-281.

Rybicka, Elżbieta (2008). „Od poetyki przestrzeni do polityki miejsca. Zwrot topograficzny w badaniach literackich", Teksty Drugie, 4, s. 21-38.

Szargotowie, Barbara i Maciej (2011). Jeżycjada a sprawa polska. O powieściach Małgorzaty Musierowicz, Katowice, Śląsk Wydawnictwo Naukowe.

Tygielski, Wojciech (2010). „Włosi”, [in] Michał Kopczyński i Wojciech Tygielski (red.), Pod wspólnym niebiem. Narody dawnej Rzeczypospolitej, Warszawa, Wydawnictwo BELLONA, s. 183-200.

\section{Netografia}

autostradadelsole.com/2017/11/wloskosc-to-jest-stan-umyslu.html [10/10/2020].

eteryt.stat.gov.pl/eTeryt/rejestr_teryt/udostepnianie_danych/baza_teryt/uzytkownicy_ indywidualni/pobieranie/pliki_pelne.aspx? contrast=default [27/07/2019].

histmag.org/Poludniowy-Tyrol-kontra-Gorna-Adyga-15551/ [10/10/2020].

hls-dhs-dss.ch/de/articles/027283/2009-04-02/ [10/10/2020].

lodz.wyborcza.pl/lodz/1,35136,4694363.html?disableRedirects=true [10/09/2020].

sjp.pwn.pl/szukaj/wloskosc.html [10/10/2020].

stat.gov.pl/statystyka-regionalna/jednostki-terytorialne/podzial-administracyjny-polski/

[10/02/2021].

uwielbiamwloskieklimaty.com/polskie-blogi-o-wloszech/ [10/10/2020].

warszawa.wyborcza.pl/warszawa/1,54420,15287880,Ulica_Rukoli_zamiast_Rzezuchowej

Tak_chcieli_w_Wilanowie.html [20/11/2020].

www.cisi.pl/ [10/09/2020].

www.collinsdictionary.com/spellcheck/english?q=italianness [20/02/2021].

www.comunecervia.it/ [10/09/2020].

www.dominik.salezjanie.pl/dominik/?d=1 [11/09/2020].

www.merriam-webster.com/dictionary/Italianity [10/08/2020].

www.straznicyczasu.pl/viewtopic.php?t=970 [10/09/2020].

www.treccani.it/enciclopedia/francesco-nullo/ [10/09/2020]. 